\title{
Kjønnsforskjeller og sosiale ulikheter i sykefravær 2000-03 blant fødte i Norge, 1967-76
}

\author{
Petter Kristensen $^{1}$ og Tor Bjerkedal ${ }^{2}$ \\ 1) Statens arbeidsmiljøinstitutt, Oslo \\ 2) Militcermedisinsk epidemiologi, Forsvarets sanitet, Oslo \\ Korrespondanse: Petter Kristensen, Statens arbeidsmiljøinstitutt, postboks 8149 Dep, 0033 Oslo \\ E-post: petter.kristensen@stami.no Telefon: 23195373 Telefaks: 23195200
}

\begin{abstract}
SAMMENDRAG
Bakgrunn: Hensikten med studien var å estimere kjønnsforskjeller og sosiale gradienter i sykefravær med varighet over 16 dager blant unge norske kvinner og menn.

Materiale og metode: Ved hjelp av registerkobling etablerte vi en populasjonsbasert kohort av alle 263605 kvinner og 286227 menn som var født i Norge 1967-76, som bodde i riket 1. januar 2000 og som hadde registrert sysselsetting under oppfølging 2000-03 (alder 23-36 år). I oppfølgingsperioden ble sykefraværet registrert i Rikstrygdeverkets (nå Arbeids- og velferdsforvaltningen, NAV) register, og sysselsettingsdata ble innhentet i FDTrygd. Antall fravær per 100 sysselsettingsår og antall fraværsdager per sysselsettingsår ble estimert, i tillegg til fireårs risiko for fravær og diagnosespesifikt fravær. Assosiasjoner med kjønn og eget og foreldres utdanningsnivå (innhentet i SSBs utdanningsregister) ble estimert i multivariate regresjonsmodeller. Analysene ble utført i subgrupper av barnløse, foreldre og vordende foreldre.

Resultater: Totalt ble 390664 fravær registrert som i varighet utgjorde mer enn 90000 år. Det var en sterk kvinneovervekt i sykefravær, spesielt under graviditet. Graviditet kunne forklare omtrent en tredel av kjønnsforskjellen. Justert hasardratio for kvinner med menn som referanse var 2,78 (95\% konfidensintervall 2,71-2,85) for barnløse, 2,01 (1,94-2,08) for småbarnsforeldre og 18,02 (17,03-19,08) for vordende foreldre. Det var en sterk og konsistent gradient med økende fravær for lavere eget utdanningsnivå, spesielt for muskel- og skjelettfravær utenom graviditet. Det var en svakere men konsistent gradient etter foreldres utdanningsnivå, også denne var sterkest for muskel- og skjelettfravær utenom graviditet. Utdanningsgradientene var nærmest fraværende for fravær under graviditet.

Konklusjon: Det ble funnet en markant kjønnsforskjell i sykefravær 2000-03 i en ung voksen befolkning som bare delvis kunne forklares av fravær under graviditet, og som ikke kunne forklares av utdanningsnivå, næringsgruppe, familietype, arbeidstid eller inntekt. Sosiale ulikheter i fravær vurdert etter eget og foreldres utdanningsnivå var sterkest for muskel- og skjelettsykdom utenom graviditet.
\end{abstract}

\section{Kristensen P, Bjerkedal T. Gender differences and social gradients in sickness absence 2000-03 among Norwegians born 1967-76. Nor J Epidemiol 2009; 19 (2): 179-191.}

\section{ENGLISH SUMMARY}

Background: The study aim was to estimate gender differences and social gradients in long-term ( $>16$ days) sickness absence among young Norwegians.

Material and methods: All live born in Norway, 1967-1976, were identified in the Medical Birth Registry of Norway and linked to several national registers by means of the unique national identification number. The study cohort included all 549832 subjects who were residents in Norway as of January 12000 and who had registered employment during follow-up 2000-2003 (age 23-36 years). Sickness absence spells were registered in the National Insurance Administration and employment history was collected in Norway's events data base (FD-trygd) during follow-up. Number of absence spells per 100 employment years and number of absence days per employment year were computed as were the four-year risk of absence and diagnosis-specific absence. Associations with gender and parental and own education level were estimated in multivariate regression models. The analyses were performed in subgroups of childless, parents, and expecting parents.

Results: A total of 390664 absence spells with a total duration of more than 90000 years was registered. The female absence excess was strong. The absence was particularly high during pregnancy, and pregnancies could explain approximately one third of the female excess. Adjusted hazard ratios for women (reference men) were $2,78(95 \%$ confidence interval $2,71-2,85)$ for childless, $2,01(1,94-2,08)$ for parents to small children and 18,02 $(17,03-19,08)$ for expecting parents. We found a strong and consistent gradient with increasing absence in association with decreasing education level, in particular for musculoskeletal absence. A weaker but still consistent gradient was found for parental education level, strongest for musculoskeletal spells as well. Absence during pregnancy showed nearly no educational gradients.

Conclusions: We found a clear gender difference in sickness absence in this young adult population. The difference was only partly explained by absence during pregnancy, and was not explained by education level, employment industry, working hours, income or family characteristics. Social inequalities in sickness absence assessed from parental and own education level was strongest for muskuloskeletal spells. 


\section{INNLEDNING}

Høyere sykefravær blant kvinner enn blant menn er et konsistent funn i forskjellige land og ulike tidsavsnitt (1-14). I Norge viser data fra $\mathrm{NHO}$ at den absolutte kjønnsforskjellen i fravær var noe mindre på 1970tallet enn senere (4), og data fra NAV på sykefraværsprosent på 2000-tallet viser en stabil kjønnsforskjell på knappe tre prosentpoeng (12). Kjønnsforskjellene i Norge er sterkest $i$ alderskategoriene mellom 25 og 39 år (12).

Det er ingen enkle forklaringer til kjønnsforskjellen i sykefravær (8). Det kan være en sammenheng med at kvinner har høyere sykelighet eller en annen egenoppfatning av helseproblemer enn menn (8). Det siste momentet har vært knyttet opp mot en hypotese om økt vulnerabilitet (mottakelighet) blant kvinner (5). Økt vulnerabilitet vil i denne sammenheng innebære at kvinner vil reagere med mer fravær enn menn som er utsatt for den samme dosen av ytre risikofaktorer. Graviditet er en fysiologisk tilstand med økt vulnerabilitet, og det er solid dokumentasjon for at risikoen for sykefravær er betraktelig økt blant gravide i arbeidslivet (15-24). Det er også sosiale gradienter i sykefravær (3, 7,25-29), og ulikheter i sosioøkonomisk posisjon mellom kjønnene kan også tenkes å forklare forskjeller i fravær. Arbeidsmiljø og forhold i hjemmet kan være risikofaktorer som kan være ulikt fordelt mellom kjønnene og som dermed kan forklare kjønnsforskjeller i sykefraværet. I arbeidsmiljøet er det for eksempel dokumentasjon på kjønnsforskjeller i belastning fra ergonomiske og psykososiale faktorer $(5,8,11)$. Betydningen av arbeidsforhold og arbeidsmiljø har vært et viktig tema i flere studier av gravide i arbeid (17-20). Forskjeller i sykefravær blant gravide har også vært knyttet opp mot graden av balanse mellom kjønnene i ulike næringer $(10,15)$. Situasjonen i hjemmet, spesielt med hensyn til sivilstatus og barnetall, er forhold som påvirker utdanning og yrkeskarriere forskjellig for kvinner og menn. Høy inntekt er assosiert med kvinner uten barn og menn med barn, og kvinnenes utdanningsfortrinn er begrenset til kvinner uten barn eller med bare ett barn (30). Sammenhengen mellom hjemmesituasjon og sykefravær har særlig blitt knyttet opp til hypotesen om kvinnens "double burden" med både jobb og mer ansvar for hjemmet enn mannen $(8,9,14$, 31-33).

Det er eksempler på studier hvor man har forsøkt å forklare kjønnsforskjellene i fravær ved hjelp av multivariat analyse hvor man har justert for helse, arbeidsmiljøfaktorer og hjemmesituasjon. I en undersøkelse av 40- til 60-årige kommuneansatte arbeidstakere i Helsinki fant man at en $25 \%$ kvinneovervekt i fravær over to uker delvis kunne forklares av forskjeller i helse og arbeidsmiljø, mens familierelaterte forhold ikke innvirket (8). I andre studier har man trukket fra alle graviditeter og sammenlignet menn med ikkegravide kvinner. I en studie fra Linköping 1985-86 ble et $50 \%$ høyere sykefravær blant kvinner halvert når gravide ble trukket fra (1). I den samme populasjonen ble høyere sykefravær på grunn av ryggsmerter nesten helt utliknet når gravide ble trukket fra (13).

For å estimere sammenhengen mellom kjønn og sykefravær og kjønnsspesifikke sosiale ulikheter i sykefravær har vi koblet individdata fra flere nasjonale registre for alle fødte i Norge 1967-76. Vi har tidligere funnet klare kjønnsforskjeller og sosiale gradienter i muskel- og skjelettsykefravær i denne befolkningen (7). For å kaste lys over observerte kjønnsforskjeller og sosiale gradienter ville vi nå analysere undergrupper av barnløse, småbarnsforeldre og vordende foreldre, samt justere for næringsgruppe, sivilstatus og andre faktorer i multivariate modeller. I tillegg til alt sykefravær vil også fravær med utvalgte diagnosekategorier studeres.

\section{MATeriale OG METOde}

\section{Deltakere og datakilder}

Utgangspunktet for studien er alle 626928 levendefødte i Norge mellom 1967 og 1976, registrert i Medisinsk fødselsregister. Ved hjelp av fødselsnummer for disse indekspersonene og deres foreldre i fødselsregisteret ble det tilkoblet data fra Det sentrale personregister, Rikstrygdeverkets (nå Arbeids- og velferdsforvaltningen, NAV) registre for sykefravær, pensjongivende inntekt og pensjonsstønader, FD-Trygd og Statistisk sentralbyrås utdanningsregister. Vi ekskluderte alle som døde $(\mathrm{N}=15800 ; 2,5 \%)$ eller emigrerte $(\mathrm{N}=25087$; $4,0 \%)$ før 1. januar 2000 og 36209 (5,8\%) som ikke hadde registrert sysselsetning i FD-Trygd i løpet av oppfølgingsperioden 2000-03. Dette ga en studiepopulasjon på 549832 indekspersoner.

\section{Data}

Studieutfallet var basert på datering og diagnose for sykefravær 2000-03, registrert i Rikstrygdeverkets sykefraværsregister (34). Dette er basert på innsendte sykmeldingsblanketter og omfatter legemeldt sykefravær ut over arbeidsgiverperioden. Arbeidsgiverperioden er 16 dager. Etter Folketrygdlovens $\$ 8-20$ kan arbeidsgiver etter søknad få unntak for dekning av sykepenger $\mathrm{i}$ arbeidsgiverperioden for arbeidstakere med langvarige eller kroniske sykdommer, eller sykdom som medfører risiko for gjentatte sykefravær. Fra 1. april 2002 ble det også adgang til slikt unntak i arbeidsgiverperioden for arbeidstaker som hadde sykefravær på grunn av svangerskap og som ikke kunne omplasseres til annet arbeid. Vi registrerte startdato og diagnose for første fravær under oppfølging. Dessuten ble det totale antall sykefravær og sykefraværsdager (summen av differansene mellom start- og sluttdato) registrert. Noen diagnosekategorier ble registrert: Muskel- og skjelettsykdom (ICPC gruppe L), mental sykdom (ICPC P), svangerskapsrelatert sykdom (ICPC W), og alle diagnoser unntatt de svangerskapsrelaterte.

De viktigste forklaringsvariablene var kjønn og utdanningsnivå. Kilden for utdanningsdata var SSBs 
utdanningsregister, hvor høyeste utdanningsnivå 1. oktober 1999 ble brukt for indekspersonene og høyesteutdanningsnivå for mor og far $\mathrm{i}$ det året indekspersonen fylte 16 år. Utdanningsnivå ble basert på standarden for utdanningsgruppering (35) og ble slått sammen i fem ordinale kategorier: Universitet (nivå 78), høgskole (nivå 6), fullført videregående (nivå 4-5), videregående, ikke fullført (nivå 3) og ungdomsskole eller lavere (nivå 0-2). Eget utdanningsnivå ble brukt som en indikator på nåværende sosial posisjon mens utdanningen til den forelder som hadde høyest nivå indikerte sosial posisjon i oppveksten.

Indekspersonenes reproduksjonshistorie var basert på registreringer i Det sentrale personregister. Dato for barnefødsler ble registrert ut 2004. Vi gikk ut fra en svangerskapsvarighet på 250 dager og beregnet om indekspersonen hadde vært en vordende forelder 200003 (i løpet av oppfølgingstiden), hvilket var tilfelle for alle med registrerte barn mellom 1. januar 2000 og 6 . september 2004. De som ikke var vordende foreldre 2000-03 ble kategorisert som barnløse eller foreldre før 2000. Beregningen av svangerskapsperiode på 250 dager ble også anvendt for å studere fravær under graviditet for de som fødte i 2001 og tilsvarende periode for vordende fedre 2001.

Sivilstatus 1999 ble registert som ugift, gift og førgift (separert, skilt eller enke/enkemann) i Det sentrale personregister og ble sammen med barnefødsler anvendt til å etablere en variabel på familietype 1999 med seks kategorier (ugift, gift, førgift uten og med barn).

FD-Trygd var kilde for data på sysselsettingsvarighet, næringsgruppe, arbeidstid, sysselsettingskategori og sosialhjelp. FD-Trygd har individidentifiserbare data på hendelser siden 1992 på disse og en rekke andre karakteristika (36). Blant alle med minst en sysselsettingsdag 2000-03 registrerte vi om de var sysselsatt ved start av oppfølging samt antall dager sysselsatt i oppfølgingsperioden. Videre ble næringshovedgruppe (10 grupper basert på NACE- kategori) og arbeidstid pr. uke (tre kategorier) registrert pr. 1. januar 2000. Sysselsettingskategori (ansatt eller selvstendig) 200003 ble delt $\mathrm{i}$ alltid ansatt, alltid selvstendig og annet. Økonomisk sosialhjelp 2000-03 ble dikotomisert.

Bostedsregion (fem kategorier) og kommunetype (syv kategorier $\mathrm{i}$ henhold til SSBs standard) ved indekspersonens 16 års alder ble innhentet fra Det sentrale personregister. Pensjonsgivende inntekt $2000 \mathrm{i}$ enheter av G (grunnbeløpet) ble innhentet fra RTVs inntektsregister.

Hendelser 2000-03 som kunne innebære sensurering (fjerning) under oppfølging ble også registrert: Dato for død og emigrasjon ble basert på FD-Trygd data, og på RTVs stønadsregister for attføringsytelser og uførepensjon.

De kategoriserte forklaringsvariabler er oppført i tabell 1. Her kan man også finne fordelingen av disse etter kjønn. Den gjennomsnittlige pensjonsgivende inntekten var 3,71 $\mathrm{G}$ for kvinner og 5,49 $\mathrm{G}$ for menn.
Tabell 1. Prosentfordeling av deskriptive karakteristika etter kjønn for 263605 kvinner og 286227 menn, født i Norge 1967-76*.

\begin{tabular}{|c|c|c|}
\hline Kategori & Kvinner & Menn \\
\hline \multicolumn{3}{|l|}{ Reproduksjonshistorie } \\
\hline Barnløs & 27,5 & 43,3 \\
\hline Forelder før $2000 \dagger$ & 29,1 & 18,3 \\
\hline Vordende forelder $2000-03 \$$ & 43,4 & 38,3 \\
\hline \multicolumn{3}{|l|}{ Eget utdanningsnivå } \\
\hline Universitet & 6,3 & 7,4 \\
\hline Høgskole & 35,7 & 23,3 \\
\hline Fullført videregående & 33,5 & 44,0 \\
\hline Videregående, ikke fullført & 19,5 & 19,1 \\
\hline Ungdomsskole eller lavere & 4,8 & 6,0 \\
\hline Data mangler & 0,1 & 0,2 \\
\hline \multicolumn{3}{|l|}{ Foreldres utdanningsnivå } \\
\hline Universitet & 6,8 & 6,8 \\
\hline Høgskole & 18,0 & 17,9 \\
\hline Fullført videregående & 20,1 & 19,8 \\
\hline Videregående, ikke fullført & 40,3 & 40,4 \\
\hline Ungdomsskole eller lavere & 14,6 & 14,8 \\
\hline Data mangler & 0,2 & 0,3 \\
\hline \multicolumn{3}{|l|}{ Familietype 1999} \\
\hline Ugift uten barn & 42,4 & 60,4 \\
\hline Gift uten barn & 5,3 & 4,4 \\
\hline Førgift uten barn & 0,7 & 0,4 \\
\hline Ugift med barn & 24,1 & 18,3 \\
\hline Gift med barn & 24,4 & 15,1 \\
\hline Førgift med barn & 3,1 & 1,4 \\
\hline \multicolumn{3}{|l|}{ Antall barn født før 1. januar 2000} \\
\hline$x_{0}$ & 48,2 & 65,1 \\
\hline 1 & 23,7 & 19,2 \\
\hline 2 & 21,4 & 12,5 \\
\hline $3+$ & 6,7 & 3,2 \\
\hline \multicolumn{3}{|l|}{ Næring, hovedgruppe (NACE kategori) } \\
\hline Industri (C) & 4,8 & 13,9 \\
\hline Bygg og anlegg $(\mathrm{F})$ & 0,7 & 10,4 \\
\hline Varehandel mv. (G) & 11,4 & 14,1 \\
\hline Hotell og restaurant (I) & 3,6 & 2,0 \\
\hline Transport $(\mathrm{H})$ & 4,3 & 9,6 \\
\hline Div. tjenesteyting $(\mathrm{M}, \mathrm{N}, \mathrm{S})$ & 18,9 & 21,5 \\
\hline Offentlig administrasjon $(\mathrm{O})$ & 5,4 & 6,4 \\
\hline Undervisning $(\mathrm{P})$ & 19,2 & 5,5 \\
\hline Helse og sosial (Q) & 36,1 & 8,1 \\
\hline Annet & 2,6 & 4,3 \\
\hline Data mangler & 1,9 & 4,3 \\
\hline \multicolumn{3}{|l|}{ Sysselsettingskategori } \\
\hline Alltid ansatt & 49,7 & 50,3 \\
\hline Alltid selvstendig & 1,8 & 3,9 \\
\hline Annet & 48,5 & 45,8 \\
\hline \multicolumn{3}{|l|}{ Arbeidstid pr. uke } \\
\hline 4-19 timer & 8,8 & 2,2 \\
\hline 20-29 timer & 10,4 & 1,4 \\
\hline 30 timer eller mer & 80,8 & 96,4 \\
\hline \multicolumn{3}{|l|}{ Sosialhjelp 2000-03 } \\
\hline $\mathrm{Ja}$ & 7,0 & 6,7 \\
\hline \multicolumn{3}{|l|}{ Bostedsregion } \\
\hline Østlandet & 40,6 & 40,2 \\
\hline Telemark og Sørlandet & 9,7 & 9,8 \\
\hline Vest & 27,4 & 27,7 \\
\hline Trøndelag & 9,6 & 9,5 \\
\hline Nord & 12,5 & 12,5 \\
\hline Data mangler & 0,3 & 0,2 \\
\hline \multicolumn{3}{|l|}{ Kommunetype } \\
\hline Sentral tjenesteyting & 29,2 & 28,9 \\
\hline Primærnæring & 6,2 & 6,3 \\
\hline Landbruk/industri & 5,9 & 6,0 \\
\hline Industri & 11,2 & 11,3 \\
\hline Mindre sentral, tjenesteyting/industri & 10,8 & 10,8 \\
\hline Sentral, tjenesteyting/industri & 28,8 & 28,9 \\
\hline Mindre sentral, tjenesteyting & 7,6 & 7,6 \\
\hline Data mangler & 0,3 & 0,2 \\
\hline
\end{tabular}

* Bosatt i riket 1. januar 2000 med registrert sysselsetting $\mathrm{i}$

oppfølgingsperioden 2000-03.

$\dagger$ Ingen barn i oppfølgingsperioden.

$\$$ Med eller uten barn før oppfølgingsperioden. 
Gjennomsnittlig barnetall var høyere for kvinnene $(1,42)$ enn for mennene $(1,02)$. Vi beregnet at 114442 kvinner gikk gravide i til sammen 84291 år under oppfølgingen, det vil si at tid som gravide utgjorde ca. $8 \%$ av kvinnenes totale observasjonstid.

\section{Analyse}

Tilrettelegging av filer og variabler ble utført i SPSS, versjon 17. Analysene ble gjennomført i StataSE 10. Vi hadde både en deskriptiv og en analytisk tilnærming $i$ analysene.

I den deskriptive delen av analysen beregnet vi andelen med ett eller flere fravær, totalt antall sykefravær og totalt antall fraværsdager i løpet av 2000-03. Rater ble også utregnet: Fraværsantall per 100 sysselsettingsår og antall fraværdager per sysselsettingsår. Vi beregnet kvinne-mannsratioen av ratene for antall fravær og antall fraværsdager. Disse analysene ble gjennomfort i hele populasjonen og i tre undergrupper: Barnløse $(\mathrm{N}=196450)$, foreldre før $2000(\mathrm{~N}=129$ 229) og vordende foreldre 2000-03 ( $\mathrm{N}=224153)$. For hvert kjønn og hver av de tre undergruppene regnet vi også ut fraværsratene stratifisert på eget og foreldres utdanningsnivå $(5 * 5=25$ strata $)$.

I den analytiske delen studerte vi undergrupper av barnløse, foreldre før 2000 og vordende foreldre 200003 . Vi begrenset analysene til personer som bare hadde vært registrert som ansatte. Blant foreldre før 2000 analyserte vi bare de som hadde små barn (fødte 199498); foreldre med barn født i 1999 ble ekskludert for å unngå personer med foreldrepermisjon i starten av oppfølgingen. Analysen av vordende foreldre ble begrenset til de som ble foreldre i 2001 med oppfølgingen fra 250 dager før fødselen til fødselen. Alle gruppene ble begrenset til de som var sysselsatt og som ikke var sykmeldt ved start av oppfølgingen. Dette ga tre grupper: Barnløse $(\mathrm{N}=141259)$, småbarnsforeldre (55 241) og vordende foreldre 2001 (48 997). For kvinner og menn i disse tre gruppene ble fireårs fraværsrisiko utregnet, risiko ble også stratifisert på eget og foreldres utdanningsnivå.

Coxregresjon med estimering av hasardratio (HR) var hovedanalyse. Tid til første sykefravær var utfallet, med sensurering 31. desember 2003 eller ved eventuell død, emigrasjon, eller mottak av attføringsytelser eller uførepensjon før første fravær. Analysen av vordende foreldre 2001 var noe forskjellig siden etablering av oppfølgingen var retrospektiv: Vordende foreldre 2001 som emigrerte eller døde ville ikke bli registrert med fødsel. Her ble tid til første fravær i løpet av svangerskapet registrert, med sensurering på dato for fødsel 2001 eller attføringsytelser eller uførepensjon før første fravær.

Vi estimerte også additive kjønnsforskjeller i multivariat binomial regresjon med justering for de samme faktorene som i Coxregresjonen. Binomial regresjon førte i noen tilfelle ikke fram på grunn av mangel på konvergens, da ble lineær regresjon benyttet.
I alle regresjonsmodeller estimerte vi assosiasjoner for kjønn (referanse mann) og eget og foreldres utdanningsnivå med justering for fødselsår, familietype, antall barn, næringsgruppe, sysselsettingskategori, arbeidstid per uke, pensjonsgivende inntekt, sosialhjelp, bostedsregion og kommunetype, det ble beregnet $95 \%$ konfidensintervall (KI).

Subanalyser ble gjennomført for å undersøke om det var variasjon av kjønnsforskjeller og sosiale gradienter i undergrupper av sivilstatus og næringsgruppe. For å vurdere den interne validiteten analyserte vi også undergruppene som var registrert med sysselsetting $\mathrm{i}$ hele oppfølgingsperioden.

\section{Resultater}

Studiepopulasjonen på 549832 personer var mellom 23 og 36 år under oppfølgingen 2000-03. Det ble det $i$ alt registrert 774083 sysselsettingsforhold, antallet forhold per person hadde et gjennomsnitt på 1,97, en median på 2 og et spenn fra 1 til 76. Totalt ble det registrert en total sysselsettingsvarighet på mer enn 1,8 millioner år, gjennomsnittlig varighet var 3,18 år for kvinner og 3,46 år for menn. Det totale antallet sykefravær var 390664 og utgjorde i varighet mer enn 90000 år. Gjennomsnittlig antall fravær per person var 0,71; medianen var 0 og det høyeste antall 82. Ekstremverdier kan forekomme ved spesielle behandlingsbehov som for eksempel dialysepasienter. Tabell 2 angir fordeling av første sykmelding etter diagnose og årsak til annen sensurering før første fravær.

\section{Kjonnsforskjeller}

Mer enn halvparten av alle kvinnene hadde hatt ett eller flere fravær i løpet av de fire oppfølgingsårene, dette gjaldt mindre enn en av fire menn (tabell 3). Fraværsratene var 2,5 ganger høyere blant kvinner enn menn. Fraværet viste store forskjeller mellom undergruppene av barnløse, foreldre før $2000 \mathrm{og}$ vordende foreldre 2000-03. For kvinner varierte det fra 34,1\% blant barnløse til $70,7 \%$ blant vordende mødre, for menn fra $17,9 \%$ blant barnløse til $33,2 \%$ blant fedre før 2000. Kjønnsforskjellene var markante i alle tre undergrupper, og størst blant vordende foreldre hvor ratene var mer enn tre ganger høyere for kvinner enn for menn. Kjønnsforskjellene var minst for foreldre før 2000 med 60-70\% høyere rater hos kvinner enn menn. Kjønnsratioene av fraværsrater var noe høyere for barnløse enn for foreldrekategoriene, men de additive kjønnsforskjellene var større for foreldre. Forklaringen på dette er at fedre hadde nær dobbelt så høyt fravær som barnløse menn.

Blant ansatte barnløse som var sysselsatte og ikke hadde fravær 1. januar 2000, var fireårs fraværsrisiko dobbelt så høy for kvinner (tabell 4). Kvinnene hadde også raskere fravær (høyere fraværsintensitet) og justert HR var 2,78. Justeringen førte til en økning av hasardratio på omtrent $20 \%$, vesentlig på grunn av 
Tabell 2. Kjønnsfordeling av første sykefravær etter diagnose og årsak til sensurering under oppfølging 2000-03 blant fødte i Norge 1967-76*.

\begin{tabular}{lrrrr}
\hline & \multicolumn{3}{c}{ Kvinner } & \multicolumn{2}{c}{ Menn } \\
\cline { 2 - 5 } Kategori & Antall & $\%$ & Antall & $\%$ \\
\hline Total & 263605 & 100 & 286227 & 100 \\
Muskelskjelettsykdom (ICPC L) & 46954 & 17,8 & 33923 & 11,9 \\
Mental sykdom (ICPC P) & 21599 & 8,2 & 10308 & 3,6 \\
Svangerskapsrelatert sykdom (ICPC W) & 34810 & 13,2 & 8 & 0,0 \\
Annen diagnose & 39638 & 15,0 & 20453 & 7,1 \\
Ufør/attføring & 133 & 0,1 & 200 & 0,1 \\
Emigrert & 901 & 0,3 & 1683 & 0,6 \\
Død & 42 & 0,0 & 358 & 0,1 \\
Fulgt ut 2003 & 119528 & 45,3 & 219294 & 76,6 \\
\hline
\end{tabular}

* Bosatt i riket 1. januar 2000 med registrert sysselsetting i oppfølgingsperioden.

Tabell 3. Sykefravær 2000-03 blant kvinner og menn født i Norge 1967-76* etter kategori av reproduksjonshistorie.

\begin{tabular}{|c|c|c|c|c|c|c|c|c|}
\hline & \multicolumn{2}{|c|}{ Total } & \multicolumn{2}{|c|}{ Barnløse } & \multicolumn{2}{|c|}{ Foreldre før $2000 \dagger$} & \multicolumn{2}{|c|}{$\begin{array}{c}\text { Vordende foreldre } \\
2000-03 \ddagger\end{array}$} \\
\hline & Kvinner & Menn & Kvinner & Menn & Kvinner & Menn & Kvinner & Menn \\
\hline Antall & 263605 & 286227 & 72416 & 124034 & 76747 & 52482 & 114442 & 109711 \\
\hline Prosentandel med fravær & 54,3 & 22,6 & 34,1 & 17,9 & 48,8 & 33,2 & 70,7 & 22,9 \\
\hline Fødselsår (gjennomsnitt) & 1971,3 & 1971,3 & 1972,6 & 1972,3 & 1969,8 & 1969,6 & 1971,5 & 1971,1 \\
\hline Sykefravær, antall & 265603 & 125061 & 45004 & 41288 & 74016 & 35367 & 146583 & 48406 \\
\hline Sykefravær, varighet (år) & 62136 & 29339 & 10455 & 10251 & 18563 & 8541 & 33118 & 10547 \\
\hline Sysselsetting (år) & 838995 & 991408 & 238933 & 409432 & 240547 & 184601 & 359515 & 397375 \\
\hline $\begin{array}{l}\text { Antall fravær per } 100 \text { sysselsettingsår } \\
(95 \% \mathrm{KI})\end{array}$ & $\begin{array}{c}31,7 \\
(31,6-31,8)\end{array}$ & $\begin{array}{c}12,6 \\
(12,5-12,7)\end{array}$ & $\begin{array}{c}18,8 \\
(18,7-19,0)\end{array}$ & $\begin{array}{c}10,1 \\
(10,0-10,2)\end{array}$ & $\begin{array}{c}30,8 \\
(30,6-31,0)\end{array}$ & $\begin{array}{c}19,2 \\
(19,0-19,3)\end{array}$ & $\begin{array}{c}40,8 \\
(40,6-40,9)\end{array}$ & $\begin{array}{c}12,2 \\
(12,1-12,3)\end{array}$ \\
\hline $\begin{array}{l}\text { Fraværsdager per sysselsettingsår } \\
(95 \% \mathrm{KI})\end{array}$ & $\begin{array}{c}27,0 \\
(26,9-27,1)\end{array}$ & $\begin{array}{c}10,8 \\
(10,7-10,9)\end{array}$ & $\begin{array}{c}16,0 \\
(15,8-16,1)\end{array}$ & $\begin{array}{c}9,1 \\
(9,0-9,3)\end{array}$ & $\begin{array}{c}28,2 \\
(27,9-28,4)\end{array}$ & $\begin{array}{c}16,9 \\
(16,7-17,1)\end{array}$ & $\begin{array}{c}33,6 \\
(33,5-33,8)\end{array}$ & $\begin{array}{c}9,7 \\
(9,6-9,8)\end{array}$ \\
\hline
\end{tabular}

* Bosatt i riket 1. januar 2000 med registrert sysselsetting i oppfølgingsperioden 2000-03.

$\dagger$ Ingen barn i oppfølgingsperioden.

$\$$ Med eller uten barn før oppfølgingsperioden.

Tabell 4. Kjønnsforskjell og sosial ulikhet i sykefravær 2000-03 blant barnløse kvinner og menn født i Norge 1967-76*

\begin{tabular}{|c|c|c|c|c|}
\hline Kategori & Antall & $\begin{array}{r}\text { Fraværs- } \\
\text { risiko }\end{array}$ & $\mathrm{HR} \dagger$ & $(95 \% \mathrm{KI})$ \\
\hline Total & 141259 & 0,245 & & \\
\hline Kvinner & 53599 & 0,357 & 2,78 & $(2,71-2,85)$ \\
\hline Menn & 87660 & 0,177 & 1 & Referanse \\
\hline \multicolumn{5}{|l|}{ Egen utdanning $\ddagger$} \\
\hline Universitet & 11376 & 0,111 & 1 & Referanse \\
\hline Høgskole & 48608 & 0,183 & 1,50 & $(1,41-1,59)$ \\
\hline Fullført videregående & 56107 & 0,261 & 2,53 & $(2,38-2,69)$ \\
\hline Videregående, ikke fullført & 19753 & 0,393 & 3,72 & $(3,50-3,97)$ \\
\hline Ungdomsskole eller lavere & 5271 & 0,383 & 3,82 & $(3,55-4,11)$ \\
\hline \multicolumn{5}{|l|}{ Foreldres utdanning $\$$} \\
\hline Universitet & 11807 & 0,148 & 1 & Referanse \\
\hline Høgskole & 29658 & 0,190 & 1,16 & $(1,10-1,23)$ \\
\hline Fullført videregående & 29278 & 0,241 & 1,30 & $(1,23-1,37)$ \\
\hline Videregående, ikke fullført & 53710 & 0,269 & 1,36 & $(1,30-1,44)$ \\
\hline Ungdomsskole eller lavere & 16418 & 0,346 & 1,54 & $(1,46-1,65)$ \\
\hline
\end{tabular}

\footnotetext{
* Bosatt i riket 1. januar 2000, ansatte som var sysselsatte og ikke sykmeldte 1. januar 2000.

$\dagger$ Hasardratio justert for fødselsår, familietype, næringsgruppe, sysselsettingskategori, arbeidstid per uke, pensjonsgivende inntekt, sosialhjelp, bostedsregion og kommunetype.

$\ddagger$ Data mangler for egen utdanning $(\mathrm{N}=144)$ og foreldreutdanning $(\mathrm{N}=388)$.
} 
Tabell 5. Kjønnsforskjell og sosial ulikhet i sykefravær 2000-03 blant småbarnsforeldre (barn 1994-98) født i Norge 1967-76*.

\begin{tabular}{|c|c|c|c|c|}
\hline Kategori & Antall & $\begin{array}{r}\text { Fraværs- } \\
\text { risiko }\end{array}$ & $\mathrm{HR} \dagger$ & $(95 \% \mathrm{KI})$ \\
\hline Total & 55241 & 0,425 & & \\
\hline Kvinner & 30591 & 0,516 & 2,01 & $(1,94-2,08)$ \\
\hline Menn & 24650 & 0,313 & 1 & Referanse \\
\hline \multicolumn{5}{|l|}{ Egen utdanning $\$$} \\
\hline Universitet & 1493 & 0,169 & 1 & Referanse \\
\hline Høgskole & 9706 & 0,342 & 1,76 & $(1,55-2,01)$ \\
\hline Fullført videregående & 24604 & 0,396 & 2,27 & $(2,00-2,58)$ \\
\hline Videregående, ikke fullført & 15079 & 0,520 & 2,93 & $(2,57-3,33)$ \\
\hline Ungdomsskole eller lavere & 4277 & 0,538 & 3,16 & $(2,76-3,61)$ \\
\hline \multicolumn{5}{|l|}{ Foreldres utdanning $\$$} \\
\hline Universitet & 1724 & 0,286 & 1 & Referanse \\
\hline Høgskole & 6773 & 0,362 & 1,16 & $(1,05-1,28)$ \\
\hline Fullført videregående & 10715 & 0,412 & 1,26 & $(1,14-1,38)$ \\
\hline Videregående, ikke fullført & 24666 & 0,432 & 1,27 & $(1,16-1,40)$ \\
\hline Ungdomsskole eller lavere & 11259 & 0,484 & 1,38 & $(1,25-1,52)$ \\
\hline
\end{tabular}

* Bosatt i riket 1. januar 2000, ansatte som var sysselsatte og ikke sykmeldte 1. januar 2000.

$\dagger$ Hasardratio justert for fødselsår, familietype, antall barn, næringsgruppe, sysselsettingskategori, arbeidstid per uke, pensjonsgivende inntekt, sosialhjelp, bostedsregion og kommunetype.

$\ddagger$ Data mangler for egen utdanning $(\mathrm{N}=82)$ og foreldreutdanning $(\mathrm{N}=104)$.

Tabell 6. Kjønnsforskjell og sosial ulikhet i sykefravær blant vordende foreldre 2001, født i Norge 1967-76*.

\begin{tabular}{|c|c|c|c|c|}
\hline Kategori & Antall & $\begin{array}{r}\text { Fraværs- } \\
\text { risiko }\end{array}$ & $\mathrm{HR} \dagger$ & $(95 \% \mathrm{KI})$ \\
\hline $\begin{array}{r}\text { Kvinner } \\
\text { Menn }\end{array}$ & $\begin{array}{l}48997 \\
26038 \\
22959\end{array}$ & $\begin{array}{l}0,531 \\
0,684 \\
0,066\end{array}$ & $\begin{array}{r}18,02 \\
1\end{array}$ & $\begin{array}{l}(17,03-19,08) \\
\text { Referanse }\end{array}$ \\
\hline $\begin{array}{r}\text { Egen utdanning } \$ \\
\text { Universitet } \\
\text { Høgskole } \\
\text { Fullført videregående } \\
\text { Videregående, ikke fullført } \\
\text { Ungdomsskole eller lavere }\end{array}$ & $\begin{array}{r}3960 \\
16797 \\
18824 \\
7416 \\
1937\end{array}$ & $\begin{array}{l}0,253 \\
0,446 \\
0,359 \\
0,444 \\
0,399\end{array}$ & $\begin{array}{r}1 \\
1,36 \\
1,63 \\
1,96 \\
2,04\end{array}$ & $\begin{array}{l}\text { Referanse } \\
(1,27-1,45) \\
(1,51-1,75) \\
(1,81-2,12) \\
(1,84-2,25)\end{array}$ \\
\hline $\begin{array}{r}\text { Foreldres utdanning } \$ \\
\text { Universitet } \\
\text { Høgskole } \\
\text { Fullført videregående } \\
\text { Videregående, ikke fullført } \\
\text { Ungdomsskole eller lavere }\end{array}$ & $\begin{array}{r}3190 \\
9041 \\
10000 \\
19985 \\
6655 \\
\end{array}$ & $\begin{array}{l}0,341 \\
0,372 \\
0,399 \\
0,402 \\
0,423 \\
\end{array}$ & $\begin{array}{r}1 \\
1,07 \\
1,17 \\
1,16 \\
1,25\end{array}$ & $\begin{array}{l}\text { Referanse } \\
(1,00-1,15) \\
(1,09-1,26) \\
(1,09-1,24) \\
(1,16-1,35) \\
\end{array}$ \\
\hline
\end{tabular}

høyere utdanningsnivå for kvinnene. Nesten alle de barnløse var ugifte $(95,5 \%)$, og HR ble ikke endret ved subanalyse av disse. Den justerte, additive risikoforskjellen assosiert med kjønn var 0,212 (95\% KI 0,2070,217). Det var bare moderate forskjeller i de ulike næringsgruppene: Størst var kvinneovervekten i helse- og sosialsektoren (additiv forskjell 0,236, 95\% KI 0,2230,248 ) og undervisningssektoren (forskjell 0,234, 95\% KI 0,219-0,248), den minste forskjellen ble funnet $\mathrm{i}$ bygg og anlegg (forskjell 0,149, 95\% KI 0,095-0,203).
Fravær var også klart assosiert med kjønn blant småbarnsforeldre med en HR på 2,01 (tabell 5). Kjønnsforskjellene var ganske like i undergruppene ugifte med småbarn ( $\mathrm{N}=25$ 092; justert HR 1,99; 95\% KI 1,89-2,09) og gifte med småbarn $(\mathrm{N}=27012$; justert HR 2,08; 95\% KI 1,97-2,19).

Oppfølging over 250 dager av 48997 vordende foreldre 2001 viste en meget sterk risikoforskjell mellom kvinner $(0,684)$ og menn $(0,066)$ (tabell 6). HR var 18,02 . 
Tabell 7. Kjønnsforskjell i ulike diagnosekategorier av første sykefravær blant fødte i Norge 1967-76*, etter kategori av reproduksjonshistorie.

\begin{tabular}{|c|c|c|c|c|}
\hline Kategori & & $\begin{array}{r}\text { Fraværs- } \\
\text { risiko }\end{array}$ & $\mathrm{HR} \dagger$ & $(95 \% \mathrm{KI})$ \\
\hline \multicolumn{5}{|l|}{ Barnløse $(N=141259)$} \\
\hline \multirow[t]{2}{*}{ Muskelskjelettsykdom (ICPC L) } & Kvinner & 0,139 & 2,27 & $(2,20-2,36)$ \\
\hline & Menn & 0,094 & 1 & Referanse \\
\hline \multirow[t]{2}{*}{ Mental sykdom (ICPC P) } & Kvinner & 0,089 & 3,68 & $(3,48-3,88)$ \\
\hline & Menn & 0,029 & 1 & Referanse \\
\hline \multicolumn{5}{|l|}{ Småbarnsforeldre $(N=55$ 241) } \\
\hline \multirow[t]{2}{*}{ Muskelskjelettsykdom (ICPC L) } & Kvinner & 0,200 & 1,52 & $(1,44-1,60)$ \\
\hline & Menn & 0,165 & 1 & Referanse \\
\hline \multirow[t]{2}{*}{ Mental sykdom (ICPC P) } & Kvinner & 0,124 & 2,68 & $(2,49-2,89)$ \\
\hline & Menn & 0,053 & 1 & Referanse \\
\hline \multicolumn{5}{|l|}{ Vordende foreldre $2001(N=48997)$} \\
\hline \multirow[t]{2}{*}{ Muskelskjelettsykdom (ICPC L) } & Kvinner & 0,189 & 10,22 & $(9,38-11,14)$ \\
\hline & Menn & 0,034 & 1 & Referanse \\
\hline \multirow[t]{2}{*}{ Mental sykdom (ICPC P) } & Kvinner & 0,018 & 3,22 & $(2,66-3,90)$ \\
\hline & Menn & 0,009 & & Referanse \\
\hline \multirow[t]{2}{*}{ Ikke svangerskapsrelatert (ikke ICPC W) } & Kvinner & 0,311 & 8,67 & $(8,15-9,23)$ \\
\hline & Menn & 0,066 & 1 & Referanse \\
\hline
\end{tabular}

* Bosatt i riket 1. januar 2000, ansatte som var sysselsatte og ikke sykmeldte ved start av oppfølgingen.

$\dagger$ Hasardratio justert for fødselsår, familietype, antall barn, næringsgruppe, sysselsettingskategori, arbeidstid per uke, pensjonsgivende inntekt, sosialhjelp, bostedsregion og kommunetype.

Fraværsrisiko og HR assosiert med kjønn i de tre undergruppene er vist for ulike diagnosekategorier $\mathrm{i}$ tabell 7. For barnløse og småbarnsforeldre var muskelog skjelettfravær vanligere enn fravær på grunn av mental sykdom, og både absolutte og relative kjønnsforskjeller var sterkest for mental sykdom. I gruppen av vordende foreldre 2001 var fraværsmønsteret annerledes. I alt 55\% ( N=9708) av kvinnenes første fravær var svangerskapsrelatert (ICPC W). For diagnoser som ikke var svangerskapsrelaterte var det en sterk kjønnsforskjell med en HR på 8,67. Kjønnsforskjellene var sterkest for muskel- og skjelettsykdom. Bare få hadde første fravær på grunn av mental sykdom, med en HR som var betraktelig mer moderat.

\section{Sosial gradient}

I figur 1 vises rater for antall sykefravær per 100 sysselsettingsår etter kategorier av eget og foreldres utdanningsnivå, i seks undergrupper oppdelt etter kjønn og reproduksjonshistorie (barnløse, foreldre før 2000, vordende foreldre 2000-03). Gjennomgående var det en klar gradient for eget utdanningsnivå i alle seks gruppene, med økende rater fra høy (universitet) til lav (ungdomsskole eller lavere). Det var tilsvarende men svakere gradienter etter foreldres utdanningsnivå. Figur 1 gir et inntrykk av svakere sosiale gradienter for kvinner enn for menn, i det minste relativt sett fordi mennene hadde rater nær null i det gunstigste stratum (universitet både selv og for foreldre), i motsetning til kvinnene som hadde rater fra 8,6 (barnløse) til 28,1 (vordende foreldre 2000-03) i tilsvarende kategori. En annen kjønnsforskjell er at mennene hadde et markant skille i fravær mellom egen utdanning på høgskolenivå og fullført videregående; kvinnene hadde ikke et tilsvarende skille i fraværstall. Spesielt for mennene var det avvik i foreldregradienten, idet menn med laveste utdanning hadde mindre fravær enn menn uten fullført videregående dersom foreldre hadde høgskole eller universitet.

Fraværsrisiko og justerte HR-estimater assosiert med eget og foreldres utdanningsnivå blant barnløse, småbarnsforeldre og vordende foreldre 2001 er vist $i$ tabellene 4, 5 og 6. Mønsteret er det samme i gruppene, med en gradient både for eget og foreldres utdanningsnivå. Gradienten for både eget og foreldres utdanningsnivå var sterkest for barnløse og svakest for vordende foreldre 2001. Gradienten for eget utdanningsnivå var betraktelig sterkere enn for foreldres utdanningsnivå; og for vordende foreldre 2001 var foreldrenes utdanningsgradient bare beskjeden. Det er også et gjennomgående trekk at gradienten for egen utdanning endret seg lite ved justering, mens foreldregradienten ble betydelig svekket av justeringen. Hovedårsaken til endringen av foreldregradienten var at effekten i stor grad ble mediert gjennom eget utdanningsnivå.

Kvinner og menns risiko for muskel- og skjelettfravær og fravær med mental sykdomsdiagnose, stratifisert på egen og foreldres utdanning, er vist i figur 2. Gruppene barnløse og småbarnforeldre er her slått sammen fordi de viste det samme mønsteret. Figur 2 viser at muskel- og skjelettfravær hadde klare og for- 

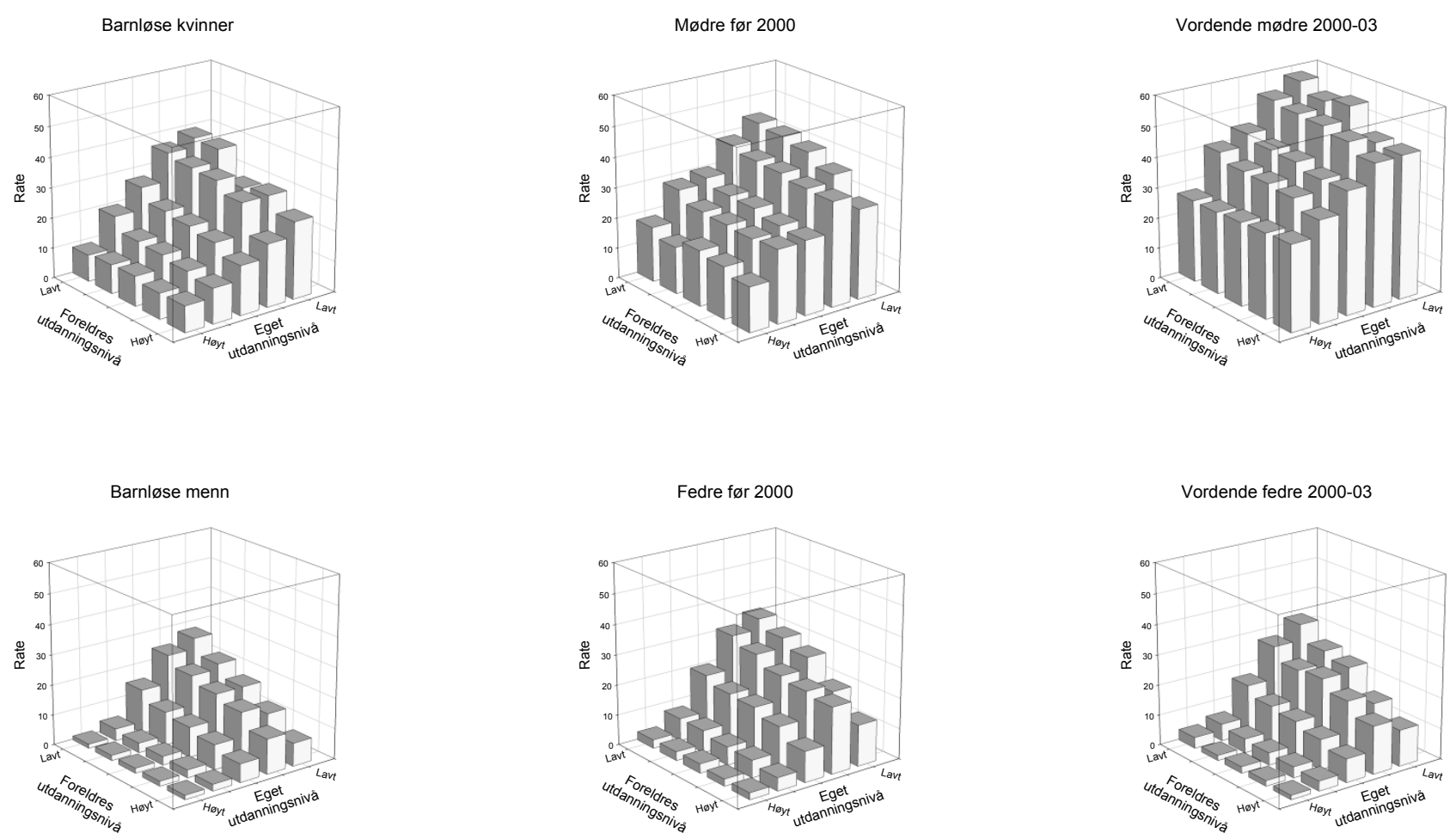

Figur 1. Antall sykefravær per 100 sysselsettingsår, 2000-03, blant kvinner og menn etter kategorier av eget og foreldres utdanningsnivå og egen reproduksjonshistorie.

holdsvis konsistente gradienter både for egen og foreldres utdanning. For menn var det et klart nivåsprang mellom høgskole og fullført videregående med hensyn til egen utdanning, et slikt sprang hadde ikke kvinnene. Mønsteret for mental sykdom var forskjellig. Det var risikoforskjeller etter eget utdanningsnivå, spesielt for menn: Mennene hadde et risikosprang mellom fullført og ikke fullført videregående skole, og den høyeste risikoen ble funnet blant de som ikke hadde fullført videregående skole. Det var ikke noe klart mønster for sammenhengen mellom foreldres utdanningsnivå og risiko for fravær med mental sykdomsdiagnose.

Relasjonene mellom eget og foreldres utdanningsnivå, og risiko for muskel- og skjelettfravær viste et helt annet mønster for gravide (figur 3). Sammenhengen med eget og foreldres utdanningsnivå var svakt og lite konsistent. For svangerskapsrelaterte diagnoser synes det som om den sosiale gradienten manglet helt.

\section{DISKUSJON}

Sykefravær ut over arbeidsgiverperioden var markant høyere blant kvinner enn menn i denne unge voksne befolkningen. Kjønnsforskjellene var betraktelig mindre for barnløse og småbarnsforeldre enn for gravide når disse ble sammenliknet med menn med gravide partnere. Kvinnene i den undersøkte populasjonen gikk gravide omtrent $8 \%$ av oppfølgingstiden. Basert på resultatene i tabell 3 kan graviditet forklare omtrent $30 \%$ av kjønnsforskjellen i fravær i våre data. Kjønns- forskjellen ble ikke svekket i multivariate modeller hvor det ble justert for blant annet utdanning, næringsgruppe og ukentlig arbeidstid, og den var sterkest $\mathrm{i}$ kvinnedominerte og svakest $\mathrm{i}$ mannsdominerte næringsgrupper. Det var en konsistent sosial gradient $\mathrm{i}$ fravær både etter eget og foreldres utdanningsnivå, sterkest var gradienten for eget nivå. Dette skyldtes i første rekke sterke gradienter for muskel- og skjelettfravær. Utdanningsgradientene for fravær i graviditet syntes å være langt svakere eller fraværende.

\section{Intern validitet}

Studien har sterke sider som skyldes sikker personidentifikasjon ved hjelp av fødselsnummer samt tilgang til flere nasjonale registere av høy kvalitet. Prospektiv kobling av individdata i nasjonale registere innebærer en nær komplett oppfølging av den store studiepopulasjonen. Det er en styrke at vi har hatt mulighet til å bygge opp data over hele livsløpet og lage forløpshistorier på for eksempel barnefødsler, sysselsetting og sykefravær, videre at data for foreldre har blitt koblet til indekspersonens data. Vi mener også at bruk av epidemiologiske standardmål på forekomst av sykefravær er en styrke i studien.

De sterke sidene gjør at muligheten for selektivt bortfall er liten, og seleksjonsbias er lite sannsynlig.

En epidemiologisk studie hvor sykefravær følges over fire år vil være svært kompleks. Tellerdata, sykefravær, baseres på dynamiske start- og slutthendelser som gjør det nødvendig med komplekse beregninger 
Muskelskjelettsykdom (ICPC L), kvinner

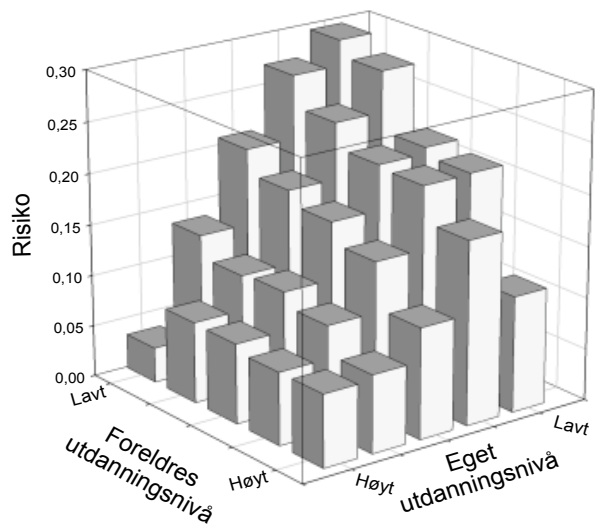

Muskelskjelettsykdom (ICPC L), menn

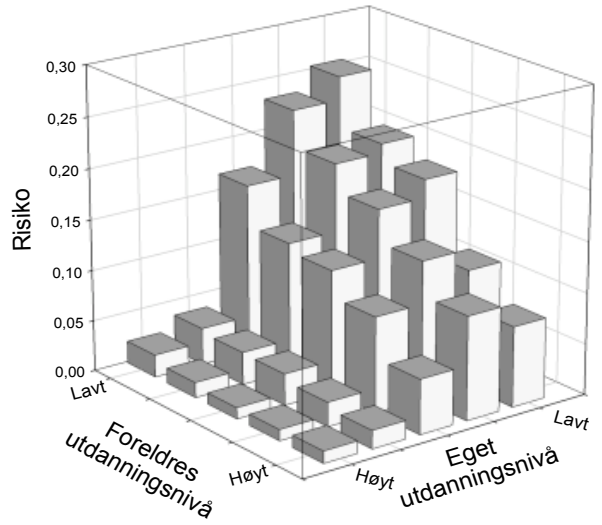

Psykiatrisk sykdom (ICPC P), kvinner

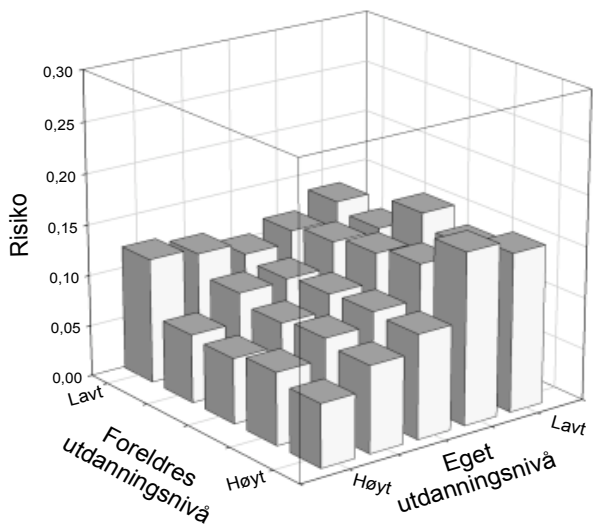

Psykiatrisk sykdom (ICPC P), menn

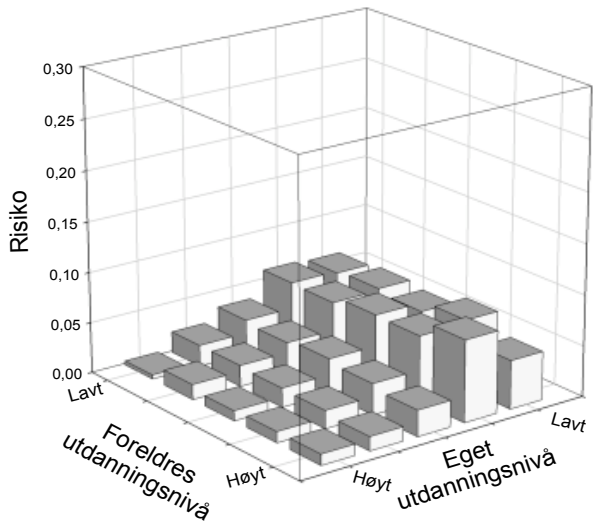

Figur 2. Risiko for sykefravær etter diagnose av første registrerte fravær, 2000-03, blant kvinner og menn* etter kategorier av eget og foreldres utdanningsnivå.

*Omfatter 149163 kvinner og 176516 menn som ikke var vordende foreldre under oppfølgingen.
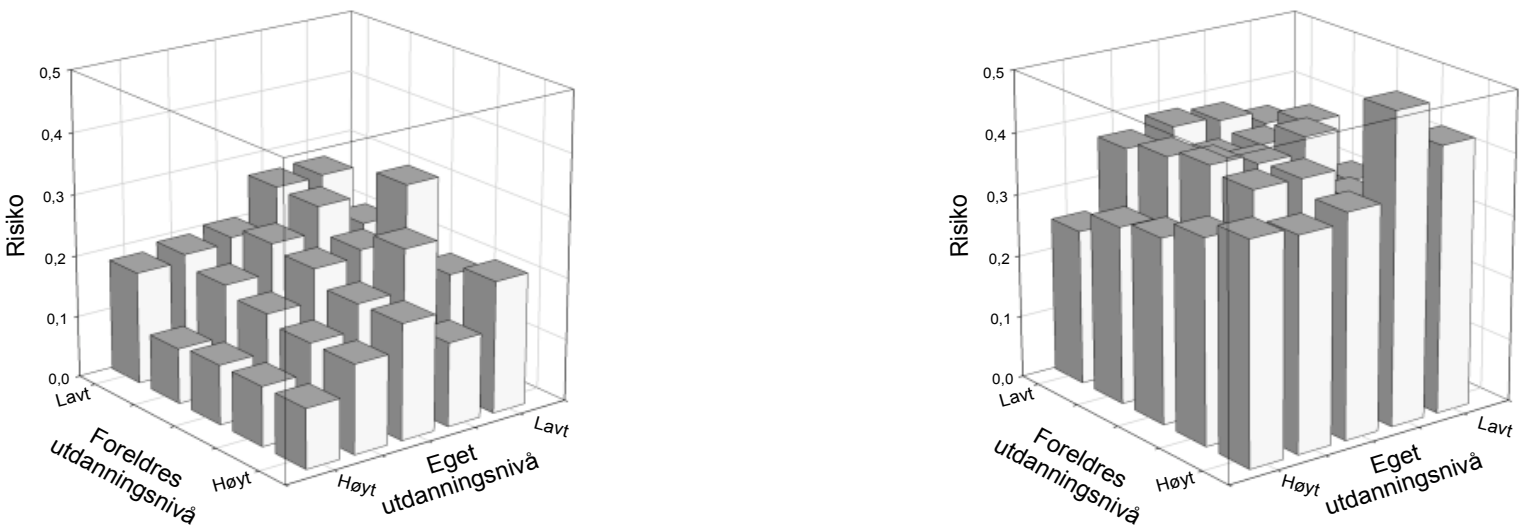

Figur 3. Risiko for sykefravær etter diagnose av første registrerte fravær, blant vordende mødre 2001 etter kategorier av eget og foreldres utdanningsnivå. 
siden noen personer har mange fravær. Kompleksiteten øker når fravær skal knyttes til endringer i sysselsettingsstatus hvor det også er en dynamikk, i tillegg til graviditeter i oppfølgingstiden. I praksis må det gjøres forenklinger som kan ha betydning for resultatene.

Et viktig aspekt er å beregne nevneren, tiden "at risk" for sykefravær. Vi har sensurert på tidspunkt for attførings- eller uføreytelser, ved emigrasjon og død. Det er andre problemer knyttet til tid under risiko som ikke har vært like lett å løse, og som kan ha ført til feil risikoestimater. I noen tilfelle kan disse også ha ført til feil i estimatene på assosiasjon, særlig forskjellene i fravær mellom kvinner og menn. For det første har vi i regresjonsanalysene ikke tatt hensyn til at ikke alle har vært sysselsatt hele oppfølgingsperioden. Videre har vi ikke tatt hensyn til tid med fødselspermisjon og tid med korttids sykefravær. Tiden under risiko for fravær (nevneren) registrert i sykefraværsregisteret er derfor kortere enn vi har registrert, hvilket vil innebære at våre risikoestimater vil være for lave. Mer alvorlig er det at kvinner har kortere tid som sysselsatte og mer tid med fødselspermisjon og korttidsfravær enn menn. Alt dette kan bety at kjønnsforskjellen i sykefravær blir underestimert i regresjonsanalysene.

Omtrent halvparten av populasjonen var sysselsatt hele perioden 2000-03, og vi analyserte denne undergruppen for å vurdere om problemet med ufullstendig tid som sysselsatt hadde noen betydning. Ny analyse av barnløse førte til en endring av HR for kvinner fra 2,78 (tabell 4) til 2,99 (95\% KI 2,89-3,10). For småbarnsforeldre endret HR seg fra 2,01 (tabell 5) til $2,18(2,08-2,29)$, og for vordende foreldre 2001 fra 18,02 (tabell 6) til 23,40 (21,40-25,59). Det synes altså som om tid som sysselsatt har hatt liten betydning for estimert kjønnsforskjell i fravær. Endringene i HRestimatene for egen og foreldres utdanning var minimale.

Vi registrerte fravær ut over arbeidsgiverperioden, hvor et ukjent antall hadde unntak fra 16-dagersregelen og derfor ble registrert første dag. Regelverket for slike unntak (FTL §8-20) ble endret i 2002 og 2003, noe som medførte at arbeidsgivere lettere kunne få unntak for gravide etter 1. april 2002. Dette kan ha medført at kvinner i kategorien "vordende foreldre 2000-03" (tabell 3) får et falskt høyt fravær og at sammenlikningen mellom kvinner og menn i denne kategorien blir skjev. Dette problemet vil imidlertid ikke påvirke resultatene for gravide 2001 (tabell 6) før lovendringene kom og heller ikke resultatene for fravær under graviditet som ikke er svangerskapsrelatert.

Påvirkningen av permisjon i forbindelse med fødsel vil kunne ha betydning for størrelsen på fraværet blant vordende foreldre 2000-03. Dersom vi antar at kvinnene hadde permisjon i samme størrelsesorden som den tiden de gikk gravide ( $8 \%$ av total oppfølgingstid), og vi antar videre at fedre hadde permisjon $1 / 4$ av denne tiden, så vil fraværsdager per sysselsettingsår stige for både vordende mødre og fedre $\mathrm{i}$ forhold til estimatene $\mathrm{i}$ tabell 3, men mest for mødrene. Med dette scenariet ville kjønnsratio for fraværsdager øke fra 3,5 til 4,1 blant vordende foreldre, og samme ratio ville for hele populasjonen øke fra 2,5 til 2,7. I så tilfelle ville forskjellene mellom totalen og de to gruppene uten barn fra 2000 bli noe større, og graviditeter ville kunne forklare ca. 35\% av kjønnsforskjellen i fravær.

Det er en kjønnsforskjell i korttids sykefravær, men dette er betydelig mer moderat enn forskjellen i lengre fravær (4). Det er derfor sannsynlig at mangelen på data på korttidsfravær bare har marginal påvirkning på de kjønnsforskjellene vi fant.

En generell svakhet ved registerbaserte studier er at noen av de tilgjengelige data er innsamlet for andre formål enn epidemiologisk forskning. Data kan derfor bli lite presise indikatorer for den informasjonen som vi egentlig er interessert i. Det kan også være andre datakvalitetsproblemer med misklassifisering. Eksempler er utdanningsnivå og klassifiseringen av tid som gravid. Det er åpenbart at ikke alle var ferdige med sin utdanning i 1999, spesielt de yngste kullene. Klassifiseringen av tid som gravide bygger på en kalkulert graviditetsvarighet på 250 dager. Dette kan diskuteres. Vi identifiserte heller ikke graviditeter som ikke endte i registrert levendefødsel i Det sentrale personregister (spontanaborter, induserte aborter, dødfødte). Vi fant $\mathrm{i}$ alt 1135 sykefravær (1,7\% av alle fravær) med svangerskapsrelatert diagnose blant de kvinnene som ikke hadde registrert fødsel etter 1999. Det er imidlertid lite trolig at misklassifisering av utdanningsnivå og tid som gravid ville være differensielt knyttet til sykefravær, og feilene vil derfor sannsynligvis føre til uttynning av de beregnete assosiasjonene.

Dataproblemer av en annen karakter er mangel på variabler som kan bidra til å forklare kjønnsforskjeller og sosial ulikhet. Dette kan oppfattes som effektforveksling (confounding) hvor forklaring på forskjellene er andre enn "kjønn" og "sosial posisjon". Det mest åpenbare er mangler på detaljerte indikatorer på helse $(8,13)$, konstitusjon og personlighet $(8)$, hjemmesituasjon (8) og arbeidsmiljø $(5,8,17-20)$.

\section{Sammenligning med andre studier}

Det er vanskelig å sammenlikne studier på sykefravær. Et forhold er forskjellene vi kan finne i fravær over tid og sted, blant annet på grunn av forskjeller og endringer i samfunnsmessige makroforhold. Et annet problem er at sykefravær måles på ulike måter, og epidemiologiske standard utfallsmål blir av og til ikke brukt. Ikke minst har det i flere studier vært vanskelig å definere og estimere tid under risiko, slik det er diskutert ovenfor.

\section{$\underline{\text { Kjønnsforskjeller }}$}

Gjennomgående fant vi sterkere kjønnsforskjeller i fravær og muskel- og skjelettfravær enn i andre studier (1,3-6,8-14). Forklaringene kan være flere. Vår studie gjelder unge kvinner og menn $\mathrm{i}$ en alder hvor kjønnsforskjellen er maksimal (12). Et annet forhold er at vi har benyttet hasardratio som mål på assosiasjon, og 
assosiasjonene blir sterkere når både risiko og intensitet bygges inn. De fleste andre studier har målt assosiasjoner basert på risiko (kumulativ risiko) eller prevalens.

Barnløse hadde det laveste fraværet, og for småbarnsforeldre var fraværet vesentlig høyere for både kvinner og menn. Den absolutte kjønnsforskjellen var dermed ganske lik i de to gruppene. Dette er ikke i samsvar med en svensk studie hvor det ble funnet høyere fravær for kvinner blant småbarnsforeldre, men ingen kjønnsforskjell blant barnløse, og hvor menn med og uten barn hadde ganske likt fravær (14). Kjønnsforskjellene for gifte og ugifte småbarnsforeldre var ganske like i vår studie, dette er ikke i samsvar med en annen svensk studie hvor single kvinner med barn hadde et markant høyere fravær enn gifte og samboende kvinner med barn (31). En forklaring på denne diskrepansen kan være svakheter i våre data på sivilstatus fordi samboende blir registrert som ugifte.

Risikoen for fravær under graviditet var som ventet dramatisk høyere enn utenom graviditet $\mathrm{i}$ vår studie, $\mathrm{i}$ samsvar med andre studier fra Skandinavia. Fraværsrisikoen over 250 dager $(0,684)$ er høyere enn ettårsrisikoen på 0,64 under graviditet i Linköping 1985-86 (21). Andelen gravide under oppfølging $\mathrm{i}$ vår studie var høy $(43,4 \%)$ og $8 \%$ av kvinnenes totale oppfølgingstid skjedde under graviditet. Dette er høyere enn $\mathrm{i}$ Linköpingstudien (5\%) hvor kvinnene var mellom 16 og 44 år (1). På tross av dette forklarte graviditet mindre av kjønnsforskjellen i fravær i vår studiepopulasjon (omtrent en tredel) enn i Linköping (omtrent halvparten). Betydningen av graviditet i Linköpingstudien var enda større for fravær med ryggsmerter hvor nesten hele kjønnsforskjellen forvant nå gravide ble trukket fra (13).

Forsterkningen av assosiasjonene mellom kjønn og fravær etter justering for forhold knyttet til sysselsetting og hjemmesituasjon var uventet. Den vesentlige forklaringen er at utdanning var en sterk risikofaktor, og kvinnene hadde høyere utdanning enn mennene. Dette står i kontrast til tilsvarende funn fra Helsinki, hvor kjønnsforskjellen i fravær over to uker blant kommunalt ansatte forsvant helt etter justering (8). En viktig forklaring kan være at det ble justert for en rekke faktorer i den finske studien som vi ikke hadde tilgang til. Noe av forklaringen kan også være at den finske studien gjaldt 40 år gamle og eldre, videre at den ujusterte kjønnsforskjellen var langt større i vår studie.

Blant de barnløse i vår studie fant vi at kjønnsforskjellen var sterkest for de kvinnedominerte næringene (helse og sosial, undervisning) og svakest for den mannsdominerte bygg og anleggsnæringen. Dette er i samsvar med et tidligere norsk funn $(10,12)$ men ikke med en svensk studie hvor kvinner i mannsdominerte næringer hadde høyest sykefravær (15).

$\mathrm{Vi}$ fant diagnostiske variasjoner i kjønnsforskjellen som ikke er klart beskrevet tidligere. Kjønnsforskjellen for mental sykdom var sterkere enn for muskel- og skjelettsykdom blant barnløse og småbarnsforeldre.
For vordende foreldre 2001 var det imidlertid omvendt: Her var assosiasjonen mellom kjønn og mental sykdom som i de andre gruppene, mens kjønnsforskjellen i muskel- og skjelettsydom ble markant skjerpet.

\section{$\underline{\text { Sosiale ulikheter }}$}

Sosioøkonomiske gradienter i sykefravær er godt dokumentert både med hensyn til posisjon som voksen $(7,26,28,29)$ og foreldrenes sosiale posisjon i oppveksten $(7,25,27)$. Vi fant at både oppvekststatus og egen voksenstatus teller, hvilket er i samsvar med disse studiene. Det er en rekke detaljer som ikke synes å være klart beskrevet tidligere. For det første var gradientene mye sterkere for muskel- og skjelettsykdom enn mental sykdom. For det andre var gradientene nærmeste fraværende hos gravide, og spesielt for svangerskapsrelaterte diagnoser. For det tredje hadde mennene et klart sprang i fraværsforekomsten mellom de med høgskoleutdanning og de med fullført videregående. Dette spranget kunne tilskrives muskel- og skjelettfraværet, og ble ikke funnet hos kvinnene. For det fjerde var det et sprang hos menn i fravær med mental sykdomsdiagnose mellom fullført og ikke fullført videregående skole, med en forekomst som var høyest hos menn med videregående skole som ikke var fullført. Det siste indikerer at den sosiale gradienten for sykefravær med mental sykdomsdiagnose har likhetstrekk med mønsteret for psykiatrisk uførhet i den samme populasjonen (37).

\section{Tolkning av resultatene}

Studien viser at det er en markant overvekt av sykefravær blant kvinner i denne unge befolkningen. Økt fravær under graviditet kan bare delvis forklare dette. Det var uventet å finne at justering for en rekke faktorer heller skjerpet enn svekket kjønnsforskjellen. Vi hadde imidlertid ikke data på helse, mestringsevne, detaljer i hjemmesituasjonen og arbeidsmiljø. Det vil for eksempel ikke være usannsynlig at arbeidsmiljøforhold kunne forklare noe av den store kjønnsforskjellen i muskel- og skjelettfravær blant høgskoleutdannete. Likevel, etter å ha justert for utdanningsnivå, næring og arbeidstid har vi vanskelig for å tro at ytterligere justering for arbeidsmiljøforhold ville få hele kjønnsforskjellen til å forsvinne. Det kan være at forklaringen på den markante kjønnsforskjellen vil være å finne $\mathrm{i}$ mer kompliserte kausale modeller som tar hensyn til samspill mellom kjønnsspesifikke individforhold og arbeidsmiljøfaktorer (5).

Det er rimelig å anta at den klare gradienten mellom egen utdanning og muskel- og skjelettfravær har en kompleks forklaring, hvor både inidividforhold, livsstil og kvaliteter i arbeidsmiljøet spiller inn. Det er vanskeligere å finne plausible forklaringer på gradienten for foreldreutdanning. Foreldres utdanningsnivå kan tenkes å være en indikator på individkarakteristika, for eksempel mestringsevne (38) eller temperament (39) som etableres tidlig i livet, siden begge egenskaper er 
assosiert med senere sykefravær $(39,40)$. En annen forklaring kunne være at foreldres utdanningsnivå influerer på fysisk aktivitet og fysiske evner i barndom og ungdomsår ved at foreldre med høyere utdanning er mer tilbøyelige til å oppmuntre barna til fysisk aktivitet (41).

De sosiale gradientene var lite uttalte for muskelog skjelettfravær under svangerskap og manglet for svangerskapsrelaterte diagnoser. Det er rimelig at gradientene blir svakere siden sykefravær omfatter mer enn to tredeler av de gravide. Forskjellene over diagnosegruppene kan skyldes en sosial gradient i diagnosesetting hvor gravide med lavere utdanning får en muskel- og skjelettdiagnose mens gravide med høyere utdanning får en svangerskapsrelatert diagnose. Det har vært en trend vekk fra muskelsskjelettdiagnoser over på svangerskapsrelaterte diagnoser i løpet av 2000-tallet (12), og det er ikke usannsynlig at denne trenden har hatt en sosial gradient. Det kan også være at ressurssterke grupper har vært flinkere til å utnytte endringene i regelverket for arbeidsgiverperioden hvor svangerskapsrelaterte diagnoser kan være økonomisk gunstig for arbeidsgiver.

\section{ETISK VURDERING}

Prosjektet er godkjent av Regional komite for medisinsk og helsefaglig forskningsetikk (ref nr. S-06028).

\section{REFERANSER}

1. Alexanderson K, Sydsjö A, Hensing G, Sydsjö G, Carstensen J. Impact of pregnancy on gender differences in sickness absence. Scand J Soc Med 1996; 24: 169-176.

2. Allebeck P, Mastekaasa A. Risk factors for sick leave - general studies. Scand J Public Health 2004; 32 (suppl 63): 49-108.

3. Brage S, Nygård JF, Tellnes G. The gender gap in musculoskeletal-related long term sickness absence in Norway. Scand J Soc Med 1998; 26: 34-43.

4. Gjesdal S. Sykefraværets utvikling i Norge 1975-2002. Tidsskr Nor Laegeforen 2005; 125: 742-745.

5. Hooftman WE, van der Beek AJ, Bongers PM, van Mechelen W. Is there a gender difference in the effect of work-related physical and psychosocial risk factors on musculoskeletal symptoms and related sickness absence? Scand J Work Environ Health 2009; 35: 85-95.

6. Indulski JA, Szubert Z. Female sickness absenteeism in Poland. Int J Occup Med Environ Health 1996; 9: 219-225.

7. Kristensen P, Bjerkedal T, Irgens LM. Early life determinants of musculoskeletal sickness absence in a cohort of Norwegians born in 1967-1976. Soc Sci Med 2007; 64: 646-655.

8. Laaksonen M, Martikainen P, Rahkonen O, Lahelma E. Explanations for gender differences in sickness absence: evidence from middle-aged municipal employees from Finland. Occup Environ Med 2008; 65: 325-330.

9. Mastekaasa A. Parenthood, gender and sickness absence. Soc Sci Med 2000; 50: 1827-1842.

10. Mastekaasa A. Sickness absence in female- and male-dominated occupations and workplaces. Soc Sci Med 2005; 60: 2261-2272.

11. Mastekaasa A, Dale-Olsen H. Do women or men have the less healthy jobs? An analysis of gender difference in sickness absence. Eur Sociol Rev 2000; 16: 267-286.

12. Myklebø S. Sykefravær og svangerskap. Arbeid og Velferd 3-2007. Oslo: NAV, 2007: 21-27. http://www.nav.no/binary/805358965/file.

13. Sydsjö A, Alexanderson K, Dastserri M, Sydsjö G. Gender differences in sick leave related to back pain diagnoses: influence of pregnancy. Spine 2003; 28: 385-389.

14. Åkerlind I, Alexanderson K, Hensing G, Leijon M, Bjurulf P. Sex differences in sickness absence in relation to parental status. Scand J Soc Med 1996; 24: 27-35.

15. Alexanderson K, Hensing G, Carstensen J, Bjurulf P. Pregnancy-related sickness absence among employed women in a Swedish county. Scand J Work Environ Health 1995; 21: 191-198.

16. Alexanderson K, Hensing G, Leijon M, Akerlind I, Rydh H, Carstensen J, Bjurulf P. Pregnancy related sickness absence in a Swedish county, 1985-87. J Epidemiol Community Health 1994; 48: 464-470.

17. Kristensen P, Nordhagen R, Wergeland E, Bjerkedal T. The influence of work environment and adjustment at work on risk of absence from work in mid-pregnancy. Occup Environ Med 2008; 65: 560-566.

18. Kærlev L, Jacobsen LB, Olsen J, Bonde JP. Long-term sick leave and its risk factors during pregnancy among Danish hospital employees. Scand J Public Health 2004; 32: 111-117.

19. Strand K, Wergeland E, Bjerkedal T. Job adjustment as a means to reduce sickness absence during pregnancy. Scand J Work Environ Health 1997; 23: 378-384.

20. Strand K, Wergeland E, Bjerkedal T. Work load, job control and risk of leaving work by sickness certification before delivery, Norway 1989. Scand J Soc Med 1997; 25: 193-201. 
21. Sydsjö A, Sydsjö G, Alexanderson K. Influence of pregnancy-related diagnoses on sick-leave data in women aged 16-44. J Womens Health Gend Based Med 2001; 10: 707-714.

22. Sydsjö A, Sydsjö G, Kjessler B. Sick leave and social benefits during pregnancy - a Swedish-Norwegian comparison. Acta Obstet Gynecol Scand 1997; 76: 748-754.

23. Sydsjö G, Sydsjö A, Wijma B. Variations in sickness absence and use of social benefits among pregnant women in a Swedish community 1978-1997. Acta Obstet Gynecol Scand 1999; 78: 383-387.

24. Sydsjö A, Sydsjö G, Wijma B, Kjessler B. Changes in sick leave rates and the use of pregnancy-associated social benefits among pregnant Swedish women: an outcomes study. $J$ Womens Health 1998; 7: 249-260.

25. Bäckman O, Palme J. Social background and sickness absence: a study of a Stockholm cohort. Acta Sociologica 1998; 41: 349-362.

26. Fuhrer R, Shipley MJ, Chastang JF, et al. Socioeconomic position, health, and possible explanations: a tale of two cohorts. Am J Public Health 2002; 92: 1290-1294.

27. Lundberg O. The impact of childhood living conditions on illness and mortality in adulthood. Soc Sci Med 1993: 36; 1047-1052.

28. North F, Syme SL, Feeney A, Head J, Shipley MJ, Marmot MG. Explaining socioeconomic differences in sickness absence: the Whitehall II study. BMJ 1993: 306: 361-366.

29. Woods V, Buckle P. Work, inequality and musculoskeletal health. Contract Research Report 421/2002. Suffolk: HSE Books, 2002.

30. Bjerkedal T, Kristensen P. Barnetallets betydning for utdanning og yrkesaktivitet: En analyse av kvinner og menn født i Norge i 1967-71 fulgt opp til fylte 30 år. I: Leira HL, red. Ingen kommer undan politiken. Festskrift til Ebba Wergeland på sekstiårsdagen. Trondheim: Transit, 2006: 57-69.

31. Voss M, Josephson M, Stark S, et al. The influence of household work and of having children on sickness absence among publicly employed women in Sweden. Scand J Public Health 2008; 36: 564-572.

32. Väänänen A, Kumpulainen R, Kevin MV, et al. Work-family characteristics as determinants of sickness absence: a large-scale cohort study of three occupational grades. J Occup Health Psychol 2008; 13: 181-196.

33. Hooftman WE, Westerman MJ, van der Beek AJ, Bongers PM, van Mechelen W. What makes men and women with musculoskeletal complaints decide they are too sick to work? Scand J Work Environ Health 2008; 34: $107-112$.

34. Bjerkedal T, Thune O. Hva koster sykelønnsordningen? Tidsskr Nor Lageforen 2003; 123: 662-663.

35. Statistisk Sentralbyrå. Norsk standard for utdanningsgruppering (Revidert 2000). Oslo-Kongsvinger: Statistisk Sentralbyrå, 2003.

36. Akselsen S, Dahl G, Lajord J, Siverstøl Ø. FD-trygd: variabelliste. Notater 2000/70. Oslo-Kongsvinger: Statistisk Sentralbyrå, 2000.

37. Kristensen P, Gravseth HM, Bjerkedal T. Social inequalities in suicide, psychiatric disability, and psychiatric sickness absence among young adult Norwegian men: influence of early life factors. Submitted, Soc Psychiatry Psychiat Epidemiol.

38. Bosma H. Socio-economic differences in health: are control beliefs fundamental mediators? I: Siegrist J, Marmot M, red. Social inequalities in health: new evidence and policy implications. Oxford: Oxford University Press, 2006: 153-166.

39. Raudsepp L. The relationship between socioeconomic status, parental support and adolescent physical activity. Acta Paediatrica 2006; 95: 93-98.

40. Kristensen TS. Sickness absence and work strain among Danish slaughterhouse workers: an analysis of absence from work regarded as coping behaviour. Soc Sci Med 1991; 32: 15-27.

41. Henderson M, Hotopf M, Leon DA. Childhood temperament and long-term sickness absence in adult life. $\mathrm{Br}$ J Psychiat 2009; 194: 220-223. 